\title{
The Effect of Teacher's Basic Skills, Learning Facilities, and Learning Motivations on Learning Outcomes: Evidence from Economic Subjects in Social Science Majors (IPS) at Padang Senior High Schools
}

\author{
Rilla Fatriyadi ${ }^{1}$, Yunia Wardi ${ }^{2}$, Susi Evanita ${ }^{3}$ \\ ${ }^{1}$ Universitas Negeri Padang, Padang, Indonesia, $\square$ rilla.fatriyadi1010@gmail.com \\ ${ }^{2}$ Universitas Negeri Padang, Padang, Indonesia, $₫$ yuniawardi@yahoo.co.id \\ ${ }^{3}$ Universitas Negeri Padang, Padang, Indonesia, $\bowtie$ susievanita@gmail.com
}

\begin{abstract}
This study aims to find out and analyze the relationship between teacher's basic skill and learning facilities on economic subjects in majors at social science, the effect of teacher's basic skill on learning motivation in economic subjects, the effect of learning facilities on learning motivation in economic subjects, the effect of teacher's basic skill on learning outcomes in economic subjects, the effect of learning facilities on learning outcomes in economic subjects, the effect of learning motivation on learning outcomes in economic subjects at Padang senior high schools. This research uses survey research. The population of the study is year eleven students at Padang senior high school, the sample consists of 257 students with a sampling technique was proportional random sampling. The result of path analysis shows: teacher's basic skill has positive impact on learning facilities, learning motivation, and learning outcomes, learning facilities has positive effect on learning motivation, furthermore learning facilities and learning motivation positively affect learning outcome.
\end{abstract}

Keywords: Teacher's basic skills, learning facilities, learning motivation, learning outcomes

\section{Introduction}

Learning outcomes are the level of success achieved by students after participating in a learning activity where the level of success is then marked by a scale of values in the form of letters, words, and symbols. The learning outcomes most often measured by researchers are student exam results (for example, Carbonaro \& Gamoran, 2002; Coleman et al 1982; Gamoran, 1996; Lee \& Bryk, 1989; Lee \& Smith, 1993, 1995; Lee et al 1997; Witte \& Walsh, 1990). Learning outcomes of economic subjects are still not optimal, in a sense, not all students reach the Minimum Completion Criteria (KKM) set by each school, namely 80. Learning outcomes are influenced by various factors both internal (inside) namely learning motivation and factors external (outside) students themselves namely the basic skills of teaching teachers and learning facilities.

According to Mulyasa (2007: 69), Teacher's basic skills are professional competencies that are quite complex and involve a variety of interrelated aspects as the integration of various teacher competencies as a whole and thoroughly. Turney (Usman, 2010: 74) reveals 8 Teacher's basic skills that are very instrumental and determine the quality of learning, namely "skills to ask, give a reinforcement, make variations, explain, open and close lessons, guide small group discussions, manage classes, and teach small groups and individuals.

According to Ehiametalor (2001), learning facilities are the facilities and infrastructure of each teaching program and are an indispensable element of teaching and learning. Lawanson et al. (2011), explains that school facilities can be defined as things that allow teachers to do their jobs very well and help students to learn effectively. Akinfolarin (2008) identifies learning facilities as the main factors that contribute to academic performance in the school system. Learning facilities are one of the important components in the process of teaching and learning activities. Adequate facilities can be seen from existing indicators, namely: the condition of the school building, space, and place of learning, media and learning aids, learning resources. 
According to Sardiman (2007: 73) that "motivation is interpreted as an effort to encourage someone to do something". Related to the explanation above Mc. Donald quoted by Sardiman (2007: 73) said that: Motivation is a change in energy in a person characterized by the emergence of "feeling" and preceded by a response to the existence of a goal. Indicators of student learning motivation: a) sincerity in learning, b) attention in the learning process, c) perseverance in completing tasks in learning, d) expectations of learning outcomes, e) feelings of pleasure in learning, and f) awareness of the benefits of learning.

The purpose of this study is:

1. to analyze the relationship of the basic skills of teaching teachers with learning facilities on economic subjects at Padang senior high schools?

2. to analyze the effect of basic teacher Teacher's basic skills on learning motivation on economic subjects at Padang senior high schools?

3. to analyze the effect of learning facilities on learning motivation on economic subjects at Padang senior high schools?

4. to analyze the effect of basic skills in teaching teachers on learning outcomes on economic subjects at Padang senior high schools?

5. to analyze the effect of learning facilities on learning outcomes on economic subjects at Padang senior high schools?

6. to analyze the effect of learning motivation on learning outcomes on economic subjects at Padang senior high schools?

\section{Methods}

This type of research is survey research. The population in this study were all students of class XI IPS (social sciences grade XI) from 16 Public High Schools in 12 Districts in Padang City. Of the 12 sub-districts selected 6 sub-districts randomly with a total population of 714 students. Calculation of the number of samples using the formula from Slavin with a large sample size of 257 people. Sampling using proportional random sampling technique.

The technique of collecting data through questionnaires related to the basic skills of teaching teachers, learning facilities, motivation to learn, and student learning outcomes, while secondary data is data on student learning outcomes. Instrument development is carried out through several stages to obtain valid and reliable instruments. Analysis of the data used is descriptive and inferential analysis.

\section{Results and Discussion}

\section{Descriptive Analysis Results}

Based on descriptive analysis all research data obtained a summary of the results as the following table.

Table 1 Results of Descriptive Analysis

\begin{tabular}{llccc}
\hline Number & \multicolumn{1}{c}{ Variable } & $\begin{array}{c}\text { Average } \\
\text { Score }\end{array}$ & $\begin{array}{c}\text { TCR } \\
\mathbf{( \% )}\end{array}$ & Category \\
\hline 1. & Basic Teacher Teacher's basic skills & 3,83 & 76,54 & Good Enough \\
\hline 2. & Learning Facilities & 3,84 & 79,16 & Good Enough \\
\hline 3. & Motivation to learn & 4,07 & 81,49 & Good \\
\hline 4. & Learning outcomes & 79,84 & - & - \\
\hline
\end{tabular}

Source: Processed Results of Research Data in 2019

The table above shows that the average value of learning outcomes of economic subjects in class XI IPS (social sciences grade XI) in Public High Schools in Padang City is 79.84.

\section{Inferential Analysis Results}

Before analyzing the research data hypothesis test, first test the analysis requirements. Based on the results of the analysis of research data it is known that the data of all research variables are 
normally distributed, and homogeneous. After the analysis requirements test is fulfilled, the hypothesis test is carried out with the following results;

\section{Substructure Analysis I}

Based on the analysis of the substructure I path, the following results are obtained;

Table 2 Results of Analysis of Substructure Path I

Correlations

\begin{tabular}{llrr}
\hline & & $\begin{array}{c}\text { Basic teacher } \\
\text { Teacher's } \\
\text { basic skills }\end{array}$ & $\begin{array}{r}\text { Learning } \\
\text { facilities }\end{array}$ \\
\hline $\begin{array}{l}\text { Basic teacher } \\
\text { Teacher's basic skills }\end{array}$ & $\begin{array}{l}\text { Pearson } \\
\text { Correlation }\end{array}$ & 1 & $0,561\left(^{* *}\right)$ \\
\hline & Sig. (2-tailed) & & 0,000 \\
\hline Learning facilities & Pearson & 257 & 257 \\
\hline & Correlation & $0,561(* *)$ & 1 \\
\hline & Sig. (2-tailed) & 0,000 & 257 \\
\hline & $\mathrm{N}$ & 257 & \\
\hline$* *$ Correlation is significant at the 0.01 level (2-tailed).
\end{tabular}

From the table above shows that the correlation of variable $\mathrm{X} 1$ with $\mathrm{X} 2$ is 0.561 , the significance level of the correlation is sig $0,000<0.05$. So it can be concluded that there is a relationship between the basic skills of teaching teachers and learning facilities in Economic Subjects of students of Class XI IPS (social sciences grade XI) in Public High Schools in the City of Padang.

\section{Substructure Analysis II}

Based on the analysis of the substructure II path, the following results are obtained;

Table 3 Results of Analysis of Substructure Path II

\begin{tabular}{|c|c|c|c|c|}
\hline $\begin{array}{l}\text { Endogenous } \\
\text { variable }\end{array}$ & $\begin{array}{l}\text { Exogenous } \\
\text { Variable }\end{array}$ & $\begin{array}{l}\text { Path } \\
\text { coefficient }\end{array}$ & $t$ count & Sig \\
\hline \multirow[t]{2}{*}{ Motivation to learn } & $\begin{array}{l}\text { Basic Teacher } \\
\text { Teacher's basic } \\
\text { skills }\end{array}$ & 0,239 & 3,470 & 0,001 \\
\hline & $\begin{array}{l}\text { Learning } \\
\text { Facilities }\end{array}$ & 0,230 & 3,338 & 0,001 \\
\hline \multicolumn{5}{|l|}{$R_{\text {square }}=0,172$} \\
\hline$\varepsilon=0,909$ & & & & \\
\hline
\end{tabular}

Table 3 shows that the basic skills of teacher teaching have a significant effect on the learning motivation of students of class XI IPS (social sciences grade XI) in Public High Schools in the City of Padang, because of the significance value (0.0001) <alpha (0.05). Furthermore, learning facilities have a significant effect on the motivation of XI IPS (social sciences grade XI) students in Public High Schools in the City of Padang, because of the significance value $(0,001)<$ alpha $(0.05)$. 


\section{Substructure Analysis III}

Based on the analysis of substructure III, the following results are obtained;

Table 4 Results of Analysis of Substructure Path III

\begin{tabular}{lllll}
\hline $\begin{array}{l}\text { Endogenous } \\
\text { variable }\end{array}$ & $\begin{array}{l}\text { Exogenous } \\
\text { Variable }\end{array}$ & $\begin{array}{l}\text { Path } \\
\text { coefficient }\end{array}$ & $\mathrm{t}$ count & Sig \\
\hline \multirow{2}{*}{ Learning outcomes } & $\begin{array}{l}\text { Basic Teacher } \\
\text { Teacher's } \\
\text { basic skills }\end{array}$ & 0,155 & 2,153 & 0,032 \\
\cline { 2 - 5 } & $\begin{array}{l}\text { Learning } \\
\text { Facilities }\end{array}$ & 0,160 & 2,231 & 0,027 \\
\cline { 2 - 5 } & $\begin{array}{l}\text { Motivation to } \\
\text { learn }\end{array}$ & 0,172 & 2,687 & 0,008 \\
\hline$R_{\text {square }}=0,146$ & & & & \\
\hline$\varepsilon=0,924$ & & & & \\
\hline
\end{tabular}

Source: Results of Primary Data Analysis in 2019

Table 4 shows that the basic skills of teaching teachers have a significant effect on the learning outcomes of students of class XI IPS (social sciences grade XI) in Public High Schools in the City of Padang, because of the significance value (0.0032) <alpha (0.05). Learning facilities have a significant effect on the learning outcomes of students of class XI IPS (social sciences grade XI) in Public High Schools in the City of Padang, because of the significance value (0.0027) <alpha (0.05). Finally, learning motivation has a significant effect on the learning outcomes of XI IPS (social sciences grade XI) class students in Public High Schools in Padang City because of the significance value $(0.0008)$ $<$ alpha (0.05).

Based on the analysis of the substructure I path it is known that the basic skills of teacher teaching are positively and significantly related to the learning facilities of XI IPS (social sciences grade XI) students in Public High Schools in the City of Padang. This is evidenced by the results of the study stating that the value of $r$ count is $(0.561)$ statistically significant because significance $(0,000)$ is smaller than alpha (0.05), so Ho is rejected. From the results of the analysis using path analysis (path analysis) that there is a significant effect of the basic skills of teaching teachers on learning motivation which is equal to 0.239 . Based on the testing of hypotheses it was found that learning facilities had a significant effect on the learning motivation of students of class XI IPS (social sciences grade XI) in Public High Schools in the City of Padang which was equal to 0.230. From the results of the analysis using path analysis (path analysis) that there is a significant effect of the basic skills of teaching teachers on student learning outcomes which is equal to 0.155 . Based on the path analysis and the results of testing the hypothesis, it is known that learning facilities have a significant effect on the learning outcomes of XI IPS (social sciences grade XI) students in Public High Schools in Padang City. The magnitude of the effect of learning facility variables on learning outcomes can be seen in the t-test amounting to $(2,231)$ with a significant $0.027<0,005$. Path analysis shows that learning motivation has a significant effect on learning outcomes seen in the path coefficients on the direct contribution of learning motivation to learning outcomes which are equal to $2.96 \%$.

\section{Conclusion}

Teacher's basic skills are positively and significantly related to the learning facilities of XI IPS (social sciences grade XI) students in Public High Schools in Padang City with a correlation coefficient of 0.561 . The basic skills of teacher teaching have a significant influence on the learning motivation of XI IPS (social sciences grade XI) students in Public High Schools in Padang City with a path coefficient of 0.239. Learning facilities have a significant influence on the learning motivation of students of class XI IPS (social sciences grade XI) in Public High Schools in the City of Padang with a path coefficient of 0.230 . Teacher's basic skills have a significant influence on the learning outcomes of students of class XI IPS (social sciences grade XI) in Public High Schools in the City of Padang with a path coefficient of 
0.155. Basic teacher Teacher's basic skills have a direct effect on learning outcomes with a contribution of 2.40. The basic skills of teacher teaching indirectly affect learning outcomes through learning motivation with a contribution of 0.64 . Learning facilities have a significant influence on the learning outcomes of students of class XI IPS (social sciences grade XI) in Public High Schools in the city of Padang with a path coefficient of 0.160 . Learning facilities have a direct effect on learning outcomes with a contribution of 2.56. Learning facilities have an indirect influence on learning outcomes through learning motivation with a contribution of 0.63 . Learning motivation has a significant influence on the learning outcomes of XI IPS (social sciences grade XI) students in Public High Schools in Padang City with a path coefficient of 0.172. Learning motivation directly affects learning outcomes with a contribution of 2.96. Learning motivation has an indirect effect on learning outcomes with a contribution of 17.20 .

\section{Reference}

Akinfolarin, C. A. (2008). Resource utilization in Vocational and Technical Education in Colleges of Education in South-West Nigeria.Unpublished Ph.D. Thesis.University of Ado-Ekiti, AdoEkiti.

Carbonar, W, J \& Gamoran, A. 2002. The Production Of Achievement Inequality In High School English. American Educational Research Journal, 39,801-827.

Coleman, J. S., Hoffer, T., \& Kilgore, S. B. 1982. High school achievement: Public, Catholic, and Private Schools Compared. New York: Basic Books.

Ehiametalor, E.T. (2001) School facilities: Management practice in Nigeria. In N.A. Nwaguru, E.T. Ehiametalor, and M.A. Ogundu, M. Nwadiami (Eds), current issues in educational management in Nigeria, 305-319. NAEAP Publication, Benin City, Ambik Press Ltd.

Gamoran, A. 1996. Student Achievement In Public Magnet, Public Comprehensive, And Private City High Schools. Educational Evaluation and Policy Analysis. 18, 1-18.

Lawanson, et al. (2011). "Provision and Management of School Facilities for the Implementation of UBE Programme". Journal of Educational and Social Research. Vol. 1. (4), 47-55.

Lee, V. E., \& Smith, J. B. 1993. Effects of School Restructuring On Achievement And Engagement Of Middle-Grade Students. Sociology Education. 66, 164-187.

Lee, V. E., Smith, J.B., \& Croninger, R.G. 1997. How high school organization influences the equitable distribution of learning in mathematics and science. Sociology of Education. 70, 128-150.

Mulyasa, E. 2007. Menjadi Guru Profesional Menciptakan Pembelajaran Kreatif dan Menyenangkan.Bandung :Remaja Rosdakarya.

Sardiman, AM. 2006. Interaksi dan Motivasi Belajar Mengajar. Jakarta : Raja Grafindo.

Usman Uzer, M. 2010. Menjadi Guru Profesional. Bandung : Remaja Rosdakarya.

Witte, J.F., \& Walsh, D. J. 1990. A Systematic Test Of The Effective Schools Models. Educational Evaluation and Policy Analysis, 12, 188-212. 